\title{
The Wesleyan Synthesis Reconsidered
}

\author{
Howard A. Snyder \\ Manchester Wesley Research Centre, Manchester, England \\ Email: has@wineskins.net
}

Submit: 14 July 2021 Revised: 28 November 2021 Accepted: 29 December 2021

\begin{abstract}
This article purpose find what is "the Wesleyan synthesis," and will also briefly revisit the much-discussed Wesleyan Quadrilateral. Wesley effectively combined in thought and practice these five elements, namely: (1) Divine sovereignty and human freedom, (2) Doctrine and experience, (3) Experience and structure, (4) Charismatic and institutional elements, and (5) Present and future salvation. This article argue that this synthesis is powerful, but also that it is biblical. In fact, the reason this synthesis is powerful is that it faithfully embodies revealed truth of Scripture. The results of the Wesleyan synthesis are draw three general conclusions. First, Wesley's theology was broader and more profound than has often been realized. Second, Wesley's theology can help us develop a biblical understanding of culture and culture change. Third, Wesley's theology is thus an open invitation to continue to develop a theology of church, mission, and culture that is profoundly biblical and sharply relevant to the present age.
\end{abstract}

Keywords: john wesley, synthesis, experience, quadrilateral, wesleyan

\section{INTRODUCTION}

True renewal in the church always weds new insights, ideas and methods with the best elements from history. This was signaled by Jesus when he said, "Every scribe who has been trained for the kingdom of heaven is like the master of a household who brings out of his treasure what is new and what is old" (Mt 13:52). ${ }^{1}$ Genuine church renewal is always a return, at the most basic level, to the image of the church as presented in Scripture and as lived out in a varying mosaic of faithfulness and unfaithfulness down through history. This is what church history shows us.

The same dynamic is at work also in culture and in deep social change. Change always combines elements from the past with new discoveries and insights in the present. Such cultural change however can be healthy or unhealthy-life-giving or lifedenying-depending on what new and old elements are combined. Unless the key elements in change are consistent with the Good News of the kingdom of God, such cultural change can do more harm than good. Social and cultural change can be enlivening or deadening.

${ }^{1}$ All biblical quotations are from the NRSV unless otherwise indicated. 
John Wesley was one key leader who combined things old and new. He was very aware of this and intentional about it. Wesley and 18th-century Methodism represent one of history's most instructive instances of the dynamic synthesis of old and new, conservative and radical, tradition and innovation. Wesley's example can spark greater clarity in today's quest to be radically Christian.

In this article i will focus on what i call "the Wesleyan synthesis," and will also briefly revisit the much-discussed Wesleyan Quadrilateral. I wrote about the Wesleyan synthesis in my book The Radical Wesley (1980), a book which was reissued in updated form in 2014. ${ }^{2}$ Today I will take a new look at the five elements of this synthesis, explaining them further, and showing their continuing relevance. I also then relate them to the Quadrilateral. I hope the relevance will be especially significant in the Korean context.

\section{THE WESLEYAN SYNTHESIS}

In a very dynamic way, John Wesley brought together several key truths and dynamics of the Christian faith. Wesley effectively combined in thought and practice these five elements, namely: (1) Divine sovereignty and human freedom, (2) Doctrine and experience, (3) Experience and structure, (4) Charismatic and institutional elements, and (5) Present and future salvation. I argue not only that this synthesis is powerful, but also that it is biblical. In fact, the reason this synthesis is powerful is that it faithfully embodies revealed truth of Scripture, as I will attempt to show.

Some commentators have said Wesley was not a very original person; that he got all his ideas from others. At one level, that is true. Certainly he was alert to learn from others. He picked up ideas and insights from those who went before, as well as from his contemporaries. But this was precisely his genius. He made connections where others did not. He learned from other people's successes and failures. He was an avid student not only of the Bible and theology, but also of history, languages, culture, and the emerging sciences of his day. ${ }^{3}$ Wesley's genius and originality lay precisely in borrowing, adapting, and combining diverse elements into a synthesis more dynamic than the sum of its parts.

2 Howard A. Snyder, The Radical Wesley: The Patterns and Practices of a Movement Maker. (Franklin, Tenn.: Seedbed Publishing, 2014).

${ }^{3}$ Randy L. Maddox, "John Wesley's Precedent for Theological Engagement with the Natural Sciences," Wesleyan Theological Journal Vol.44, No.1 (2009): 23-54. 
For example: the Bible says salvation is all of grace, not of works. It also says we are to work out our own salvation. Faith without works is dead. Wesley's way out of this paradox was through Galatians 5:6, "faith working through love." This became a favorite passage and theme. It is practically a refrain in Wesley: Faith working through love. True faith had shed God's love abroad in Wesley's own heart, and that became the fountainhead of "all inward and outward holiness"-another key conjunctive Wesley refrain.

Wesley's genius, under God, lay in developing and nurturing a synthesis in doctrine and practice that kept biblical paradoxes paired and powerful. He held together faith and works, doctrine and experience, the personal and the social, the concerns of time and eternity. His dynamic synthesis speaks profoundly to the church today. I invite you then to examine the key elements of the Wesleyan synthesis, noting how these tie in to the life and experience of today's church.

\section{Divine Sovereignty and Human Freedom}

Basic to all else in Wesley was his tenacious hold on both the total sovereignty of God and the freedom of human beings. God gives humans the freedom to accept or reject God's call, and then to cooperate with the Holy Spirit in the work of salvation. This is true for each particular person, and its true in believers collectively as the church. It is true also in terms of how the whole world responds to God's gracious initiative. God gives people and societies freedom to accept or reject his grace, within the limits he has set.

Wesley's starting point was not the so-called "decrees of God." Nor was it the logical question of how to resolve a theological paradox. Wesley's starting point was, rather, what Scripture teaches: God is sovereign; besides him there is no other god; all salvation depends on his initiative and working. But humans, even though sinful, still have a measure of real freedom. If they turn to God, they can be his coworkers in the local and cosmic concerns of God's kingdom. This is what John Wesley learned from the Old Testament and from Jesus and his Apostles, particularly from Paul, John, and Peter.

Wesley stressed the image of God as well as the Word of God. Human creation in the divine image was fundamental for Wesley because it meant a deep, permanent similarity between the human spirit and the Spirit of God. This similarity, this image, is something which even the tragic effects of the fall could not destroy. Salvation was still 
possible. But only by God's grace, because sin put men and women under such bondage that they could never freely turn to God.

Like Gregory of Nyssa and other early teachers of the Eastern Church, Wesley saw the will as essential to the image of God. God has given women and men a will either to serve him or to rebel against him. Now, because of sin, the will is under bondage. People choose to do evil rather than good. Salvation therefore means restoring the image of God and freeing the will to do God's will.

By grace alone, men and women can will to serve God. The highest perfection in Christian experience is to serve God with the whole mind, heart, and will. In a passage typical of many others, Wesley says that true Christianity is "the love of God and our neighbour; the image of God stamped on the heart; the life of God in the soul of man; the mind that was in Christ, enabling us to walk as Christ also walked."4

The key to Wesley's skill in stressing both God's sovereignty and human freedom was his doctrine of grace, particularly his accent on "prevenient grace." On their own, human beings cannot take the smallest step toward God. But God has not left us alone. An unconditional benefit of Christ's atonement is that God maintains the human race in a savable position. God's grace is "prevenient"; that is, it "goes before" (Latin, praevenire, to come before, anticipate) us, giving us the capacity, if we will, to turn to God. We could call this "preceding grace." Yet even this turning toward God is aided by God's grace shed abroad universally in the world by the death and resurrection of Jesus Christ.

John Calvin spoke of common or general grace. He used the concept of common grace to explain how even totally depraved persons can do commendable (if not morally good) works. Unlike predestination, this is an unconditional blessing of God in the world. But due to Calvin's doctrine of unconditional election, common grace plays no part, finally, in God's plan of redemption.

In sharp contrast, Wesley saw prevenient grace as the first step in God's redeeming work. Even though people could reject God's grace-and most would-yet the offer was real and constant. Wesley saw God's grace as "preventing [or coming before], accompanying, and following" every person, as he said in his sermon "The Good Steward."5 Thus God is sovereign and man and woman are free. In Colin Williams'

${ }^{4}$ Wesley's Journal in The Works of John Wesley (Bicentennial Ed., Abingdon Press), 22:55 (Aug. 27, 1768). (All references to Wesley's Works are from this multi-volume edition unless otherwise noted.)

5 Sermon 51, "The Good Steward," Works, 2:296. 
words, with the doctrine of prevenient grace Wesley "broke the chain of logical necessity by which the Calvinist doctrine of predestination seems to flow from the doctrine of original sin."6

Because of his emphasis on human freedom and the universality of the atonement, Wesley has often been considered an Arminian. But this is so only in a qualified sense. Methodists "come to the very edge of Calvinism," Wesley said: "(1) In ascribing all good to the free grace of God; (2) in denying all natural free will and all power antecedent to grace; and, (3) in excluding all merit from man, even for what he has or does by the grace of God."7 As George Croft Cell noted, Wesley (in his sermon "Salvation by Faith") "goes as far as Paul, Augustine, Luther or Calvin ever did or could go in pressing to the limit the exclusive causality of God in man's experience of salvation as well as in any and all provisions of redemption." 8

Taking Wesley's whole system into account, it is therefore something of a distortion to speak of "Wesleyan-Arminianism." We could as truly speak of "WesleyanCalvinism," remembering that Arminius himself was in most points a Calvinist. There is however a very fundamental difference between John Calvin and John Wesley at the point of God's character and his decrees. I will say more about this in the second lecture.

Wesley was as fully conscious as the earlier Reformers were of God's grace and sovereignty. But he had a deep optimism of grace that formed the foundation for his emphasis on the universal atonement, the witness of the Spirit, and Christian perfection. He saw God's grace so fully abounding that one could not set limits on what God's Spirit might accomplish through the church in the present order.

People who don't fully understand Wesley at this point have sometimes called him "Semi-Pelagian" or even "Pelagian." That is, they accuse Wesley of teaching some form of works-righteousness, that justification comes through our own efforts or actions.

Wesley strongly denied this. His emphasis on the prior operation of God's grace, illustrated in the quotations above, fully clears him of such charges. ${ }^{9}$ Roger Olson's apt

\footnotetext{
${ }^{6}$ Colin Williams, John Wesley's Theology Today (Nashville: Abingdon Press, 1960), 44.

${ }^{7}$ Minutes of 1745 Conference, Works, 10:153.

8 George Croft Cell, personal letter quoted in E. D. Soper, "Grace in Methodist Tradition," in W. T. Whitley, ed., The Doctrine of Grace (New York: Macmillan, [1932]), 286.

9 The reference is to the teachings of Pelagius (354-420? AD), who is alleged to have taught that despite the fall, humans remain capable of choosing good, not just evil. Semi-Pelagianism generally means
} 
comment about Arminianism applies fully to Wesley: "Contrary to confused critics, classical Arminianism is neither Pelagian nor semi-Pelagian! But it is synergistic. Arminianism is evangelical synergism as opposed to heretical, humanistic synergism."10

"Evangelical synergism" is an apt term, and it fits Wesley perfectly. Synergism, because there is a real working-together, a real co-operation. But evangelical, because it is enabled essentially by God's grace, the Good News.

Wesley's dynamic view is important not just for each particular person. It also preserves an essential and hopeful role for the church. It is optimistic as to the moral transformation of human beings (the restoration of the image of God) made possible by grace. And it sees the church as the instrumental means for promoting redemption in personal experience and in society. Wesley's view takes the church very seriously as an agent of grace in the world. Wesley's theology therefore speaks to the contemporary need to build a more radical and biblical ecclesiology and especially a more biblically faithful community of believers.

In affirming both divine sovereignty and human freedom, Wesley does not endorse paradox or contradiction or illogic. Rather, he affirms superior divine wisdom. The ultimate answer to the seeming paradox of sovereignty and freedom is the marvelous loving, sovereign wisdom of God. ${ }^{11}$

\section{Doctrine and Experience}

Because of his double accent on both divine sovereignty and human freedom, Wesley focused on Christian experience. He looked for moral transformation in believers' lives, demonstrated by their behavior. Thus Wesley stressed both doctrine and experience-once again, "faith working through love." If faith didn't produce moral change, including good works, it wasn't true faith. Thus also Wesley's concern with sanctification: The New Birth began and enabled the process of sanctification. So every believer was morally obligated to "press on to perfection." Justification and sanctification went together. Wesley said of the Methodists:

That, as they do not think or speak of justification so as to supersede sanctification, so neither do they think or speak of sanctification so as to supersede justification...

that sinners may turn to God by their own free will, which God then assists. Whether Pelagius himself actually taught "Pelagianism" remains a question.

${ }^{10}$ Roger Olson, Arminian Theology: Myths and Realities (Downers Grove: InterVarsity, 2006), 18.

11 God's wisdom was a frequent emphasis in Wesley, as noted in Lecture II. 
Therefore they maintain with equal zeal and diligence the doctrine of free, full, present justification on the one hand, and of entire sanctification both of heart and life, on the other-being as tenacious of inward holiness as any mystic, and of outward [holiness] as any Pharisee. ${ }^{12}$

This is from Wesley's sermon, “On God's Vineyard." Here Wesley explicitly takes Luther to task for underemphasizing sanctification.

Wesley's oft-repeated stress on both inward and outward holiness is evidence of this balance of doctrine and experience. An inner experience of God in the soul that does not result in one's "doing all the good you can" is inherently suspect. Wesley's concern for sanctification simply shows he really believed that doctrine and experience go together. Men and women do not truly believe the gospel without a moral change which enables them to live the gospel. Faith not only believes; it works. It accomplishes good works, and thus is functional, effective. ${ }^{13}$

This balancing of doctrine and experience shows itself also in Wesley's dual stress on reason and experience. At the high tide of Deism, Wesley stressed that faith was rational and reason was its handmaid. Even when criticized as a mad enthusiast, Wesley still insisted on the conscious sense of God in the soul and on the inner witness of the Spirit.

This balanced emphasis on doctrine and experience gave Methodism a strong ethical sensitivity. But it also underscored the important role of the church. Wesley knew the Christian community was either the environment where God's grace turned sinners into saints or else a cold, lifeless shell where newborn believers died of spiritual exposure. Wesley would join those voices in our day calling for the recovery of such a balance of doctrine and experience.

\section{Experience and Structure}

This leads to an aspect of the Wesleyan synthesis that has great potential impact for the church today. Wesley saw the vital link between experience and structure. Perhaps no one in church history (unless Ignatius Loyola) was more keenly aware of the connection between Christian experience and necessary nurturing structures to help maintain and nurture the experience. No one was so successful in matching church

12 Sermon 107, “On God's Vineyard,” Works 3:507.

13 It is important to note that Wesley's concern was not primarily for subjective inner spiritual experience per se, but for the inward working of God's Spirit in the heart evidenced by truly Christ-like behavior in the world- "Justice, mercy, and truth," as Wesley often phrased it. 
forms to church life! Certainly Wesley was more successful at this point than Luther in Saxony, or Calvin in Geneva, or even Zinzendorf in Herrnhut-Zinzendorf, who helped launch the remarkable worldwide Moravian missionary movement.

Wesley's system of societies, classes, and bands was the central structural genius that facilitated the discipline, growth, and enduring impact of Methodism. To these were added many other structures, such as schools, dispensaries, and loan funds for those in need. The Methodist system grew out of Wesley's keen awareness of the social nature of Christian experience. Wesley understood the balance of person and community. He understood that for spiritual growth, a Christian disciple needs Christian community, and the Christian community depends for its vitality on the continuing growth of its members.

As early as 1729 a "serious man" told Wesley, "Sir, you wish to serve God and go to heaven? Remember that you cannot serve him alone. You must therefore find companions or make them; the Bible knows nothing of solitary religion." 14 Wesley followed this advice for the next sixty years, always avoiding "solitary religion." This concern for vital community was at the heart of his reservations about mysticism-that is, a private, interior spirituality that fails to express itself in community and in redemptive action in the world.

Wesley used the terms "social holiness" and "social Christianity." In doing so, he was pointing to New Testament koinonia. Christian fellowship meant, not merely corporate worship, but watching over one another in love. It meant advising, exhorting, admonishing and praying with the brothers and sisters, as the New Testament instructs us. 15 "This, and this alone, is Christian fellowship," Wesley said. And this is what Methodism promoted. Wesley affirmed, "we introduce Christian fellowship where it was utterly destroyed. And the fruits of it have been peace, joy, love, and zeal for every good word and work."16

The great instrument for building vital community or fellowship was the Methodist system of society, class meeting, and band. For Wesley, the class meeting was an ecclesiological statement, integrally linked to sanctification. That is, the class meeting was an affirmation and embodiment of what the church really is. In Wesley's view, if

14 John Telford, The Life of John Wesley (New York: Phillips and Hunt, 1886), 147; Sydney G. Dimond, The Psychology of the Methodist Revival (Oxford: Oxford University Press, 1926), 209.

15 See Sermon 65, "The Duty of Reproving Our Neighbour," Works, 2:511-20.

16 Plain Account of the People Called Methodists, Works, 9:259 (emphasis Wesley's). 
believers were really serious in their quest for holiness, they would band together in small groups to experience that level of community which is the necessary environment for growth in grace.

Students of Wesley and of spiritual renewal often discover or rediscover the relevance of Wesley's practice structures, particularly the class meeting. ${ }^{17}$ It is ironic that many books on Wesley deal only briefly with the class meeting, even though Wesley himself saw it the cornerstone of Methodism. Many who have advocated Wesleyan theology through history and today have forgotten this practical small-group structure and thus have tended to over-individualize Wesley's social concept of sanctification and to lose the secret of much of the spiritual power of early Methodism. Wesleyan theology without Wesley's structural practice is not true Wesleyan theology. It is deficient.

Richard Lovelace was surely right in thinking that the decline of the class meeting in large measure explains the decline of Methodism. Referring to the class meeting, Lovelace commented, "It is startling that a strategy as obvious and effective as small groups could be discovered and widely used in recent history and then apparently lost until its modern rediscovery in popular religious movements. A generation of formal Christians intervening between awakenings appears sufficient to erase them from the church's memory."18

What Lovelace meant is this: The importance of the class meeting is obvious once you understand how it works. When such structures are abandoned or lose their intimacy and vitality, the church's overall vitality declines. The church then gradually becomes an institution, rather than an organism. Before long the church completely forgets what it once new: That vital, nurturing small groups are essential. The church suffers until it finally rediscovers such groups as God again begins to renew his church.

The key point here is that experience and structure must go together, and that structures must nurture and help extend vital Christian experience rather than replacing it. Structures are to serve the church's vitality and mission. The church is not

17 Thomas Oden for example noted the similarities of modern "encounter groups" to the Methodist class meeting and other eighteenth-century antecedents, arguing that these were "the basic prototypes" of the modern movement, existing "on a vast scale in a highly refined form as a vigorous and popular lay movement." Oden, Intensive Group Experience, The New Pietism (Philadelphia: Westminster, 1972), 56-88; especially 59.

18 Richard F. Lovelace, Dynamics of Spiritual Life: An Evangelical Theology of Renewal (Downers Grove, III: InterVarsity Press, 1979), 167. 
to serve the structure. This is another way of stating what Jesus said about wine and wineskins.

The implication for today's church is obvious: the church must recover some functional equivalent of the class meeting with its intimacy, mutual care and support, and discipline. Such a rigorous structure as the early Methodism class meeting naturally goes against the grain in a lax, individualistic, live-and-let-live society. But this is precisely why it is needed. Talk of discipline, discipleship, and responsible Christian living and witness seldom gets beyond mere talk until folks make a serious covenant commitment to each other to be in community together. We need structures that help Christians actually embody in their daily lives what they profess to believe. Such small covenant communities show that believers are willing to ratify their commitment to Christ by commitment to his body. Only in this way do we begin to understand in practice the truth that "we are members of one another" (Eph. 4:25).

The discipline and rigor of the class meeting were no less scandalous in Wesley's day than they are today. Wesley saw however that such covenant structures were essential if Christians were to make a successful stand against the world, the flesh, and the devil and to be gospel leaven in society. Some people may say, "But people today won't make such costly commitments." Yet people do commit themselves to health clubs, sports teams, special classes, and other groups that capture their interest. They make time for them. At heart, the issue is not time or willingness to commit to something. The problem is priorities. What really is most important in our lives?

In any age when Christian values are in near-total eclipse, only a close-knit countercultural expression of the church will have the spiritual and social power to speak a gospel word to the dominant spirit of the age. History shows that an infrastructure of "little church" groups of some sort is indispensable to sustained countercultural witness. In church history such groups have often been called eclesiolae, a Latin term meaning little churches within the larger church. ${ }^{19}$

\section{The Charismatic and the Institutional}

19 On ecclesiola groups, see Howard A. Snyder, Signs of the Spirit: How God Reshapes the Church (Grand Rapids: Zondervan, 1989), especially 35-39. I have argued at length, on biblical and pragmatic grounds, for some form of small group structure in The Problem of Wineskins (Downers Grove. Ill.: InterVarsity, 1975) and in Community of the King. I would add here the importance of covenant, discipline, mutual exhortation, and provision for exclusion of those who consistently break covenant in the use of small groups. 
Wesley balanced what I call the charismatic and the institutional aspects of church life and experience. He held together creatively, synergistically, the dynamic of the gracious work of the Spirit through his gifts, and those aspects of church life that have to do with organization and structure. This of course is related to the dynamic tension between experience and structure. But here I am speaking about two basic tendencies we always find in the church: the charismatic tendency and the institutional tendency. Let us compare and contrast the institutional view and the charismatic view.

The Institutional View. From this perspective, the church is God's saving institution on earth. Church history is seen positively as the unfolding drama of God's purposes. Existing structures of the church (theological and especially organizational) are not fundamentally questioned. Periods of decline or unfaithfulness in church history stem from the personal character of church leaders or external factors, but not from the church-as-institution itself. In fact, the institutional stability and survival of the church in spite of periods of decline, opposition, or weakness are seen as part of the glory and indestructibility of the church. They reveal God's providence in establishing the church as the institution of salvation.

Thus from a Roman Catholic perspective, the survival of the papacy in spite of periods of corruption or weakness attests to the church's validity. Similarly, from a Protestant perspective, the endurance of preaching or the "ministerial office" is seen as a source of God's renewing work even when many people are unfaithful.

From this perspective, nothing is ever fundamentally wrong with the church. The question of church renewal therefore is exclusively (or nearly so) a question of the spiritual renewal of particular persons or the general body of believers. As someone told the Pietist reformer Philip Jakob Spener, "It is not the Church but the ungodly in the Church that must be reformed." 20 The problem is simply that people fail to believe or act as the church tells them to. Renewal, however it comes, means restoring people to the level of belief or action defined by the church as normal. Any genuine renewal is seen as beginning with the ecclesiastical leaders and affecting the whole church more or less evenly.

In important ways, John Wesley shared the institutional perspective. He was an "institutionalist." He affirmed the traditions and structures of the Church of England. He

20 Quoted in Isaac Dorner, History of Protestant Theology, trans. George Robson and Sophia Tucker (Edinburgh: T. and T. Clark, 1871), 2:211. 
was a defender-but also a critic-of the institutional church in England.

The Charismatic View. In contrast to the institutional view, the charismatic view insists that the church must always be in direct contact with God's Spirit and a clear channel of his grace (charis) in order to have life and power. The church is essentially a spiritual organism and community, whatever its institutional form. Institutional forms are viewed ambivalently or are even totally rejected.

The charismatic view naturally sees church history in a different light from the institutional view. History and tradition do not in themselves validate the present form of the church. What is important is immediate and direct spiritual life now, today. History is evaluated according to evidence of such life at various points in the past, and according to whether past events have contributed to or undermined the church's spiritual life. The charismatic view is especially attracted to the New Testament church. However it may have a simplistic, idealized view of the early church. The charismatic view measures both history and present state of the church by this picture (a phenomenon called primitivism). Often this perspective holds to the concept of the fall of the church and therefore to the present need to restore the church to its primitive purity (called restitutionism).

Typically, the charismatic view is concerned with the entire experience of the church, not just its structures. It wants to see visibly renewed Christian communities, not just private personal renewal. This puts the charismatic view in conflict with the institutional view, because champions of the charismatic view often correctly perceive that many obstacles to renewal are enshrined in traditional institutional forms. Either these forms must change or else a more renewed and virile form of Christian community must be implanted within or replace the institutional church so that the charismatic ideal may become a reality. ${ }^{21}$

Are the charismatic and institutional perspectives mutually exclusive? No. But it is very hard to combine them and hold them in helpful tension. Yet this is precisely what John Wesley did. Wesley affirmed both the necessity of a present, vital experience of Christian community and discipleship, and also the validity of the church in its more institutional forms. By themselves, both the institutional and charismatic views have their problems. The institutional view is often blind to the great gulf between the

\footnotetext{
${ }^{21}$ I deal with these dynamics at more length and propose a model for church renewal in Signs of the Spirit, Chapter 7, 270-281.
} 
church's profession and its possession. Often it fails to see its own institutionalism and self-interest in resisting change. Consequently it often denies the truth in the charismatic claim and misreads the importance of renewal movements. It may find itself in the unfortunate position of fighting in practice the very life it favors in theory.

But the charismatic view too has its problems. Renewal leaders often have no sense of history, or force history into their own framework. They too easily identify God's purposes exclusively with their side in the renewal debate. They are typically naïve concerning institutional and sociological realities and blind to institutionalizing tendencies in their own movement. Also, in their concern with present experience they may fall prey to bizarre apocalyptic, dispensational, or millennial views which are unbiblical and unrealistic and may lead to extreme hopes, claims, or actions. They also may fall prey to authoritarian, status-seeking leaders who glorify themselves more than they build genuine community and mutuality.

It is partly for these reason that some renewal folk burn out and seek liturgical worship for its sense of history, stability, mystery, and deep tradition. In fact, both the institutional and charismatic views have their strengths. Both have something to offer the church. Wesley clearly understood this. Whatever the church's state of decline, usually it still carries the Scriptures, the sacraments, and a deposit of Christian doctrinal truth. We might call this historical Christian DNA.

If we examine church history carefully, we see some real continuity-and therefore some degree of validity-in the institutional church. Otherwise any renewal movement would be a totally new, unique, and unprecedented phenomenon, a church generated uniquely by the Spirit's action unrelated to history. Such a view would be unbiblical as well as sociologically and historically naïve.

On the other hand, the charismatic view cannot simply be dismissed. Institutions decline and need periodic renewal. When the institution is the church, renewal certainly must spring from a new or renewed experience of God's grace, whatever other features it may have. Furthermore, the charismatic stress on community and on charismatic (rather than institutional, authoritarian) leadership often points to real problem areas in the institutional church. Many renewal movements are in fact quite dynamic. Historically, the dynamism of renewal movements has often contributed hugely to the renewal or rebirth of the institutional church itself. Early Methodism was itself a prime example of this. So was the Franciscan movement. There are many other examples not 
only in Protestantism but also in Roman Catholicism and the Orthodox tradition.

Since both the institutional and charismatic perspectives have something positive to contribute to the church's life and mission, it makes sense to combine them in some way. That is, we should not try to steer a middle course between the institutional and the charismatic, but rather incorporate the truth of both dynamics. This is precisely what John Wesley did.

Some biblical analogies may be useful here. Most biblical figures of the church are figures from life-body, tree, vine, marriage, and so forth. Note especially a key figure found in Isaiah 11 and elsewhere-the figure of an old, partially deadened growth sending forth new shoots. "A shoot shall come out from the stock of Jesse, and a branch shall grow out of his roots" (Isa 11:1). Renewal movements seem almost instinctively drawn toward such analogies. The movement represents "new life," a" sprouting forth of new growth. But the analogy necessarily implies also that some life still remains in the old stump. Both the new and the old have come from the same deep roots.

The stump-and-branch metaphor suggests an interdependence or symbiosis between the institutional church and the renewal movement. The image implies that, for whatever reason, the stock has lost an earlier vigor, but that it still has life, and therefore hope. And it recognizes that the new branch has not sprung into being simply on its own but to some degree has its source in the old stock.

Wesley emphasized both the new work of the Spirit in his day and also the value of Anglican forms and traditions. This dynamic double emphasis fits into the larger picture of Wesley's understanding of the church and Christian experience. This is Wesley's view of the church and how God works in and through it.

The curious thing about early Methodism is that it was a charismatic church within the institutional church. Many point to Methodism's separation from the Church of England as sure proof of the inevitable failure of Wesley's theory and approach. But this outcome was not really inevitable, and it does not mean that Methodism was in the end a failure. Look at the historical circumstances. They are important. We see three facts: (1) Wesley was never expelled from the Church of England. (2) He never left the Church or permitted Methodism to do so. And (3) the Anglican Church never gave Methodism any kind of official status. Had these circumstances been different, the outcome likely would have been different.

Wesley was never expelled from the Anglican Church. Nor was he ever 
disciplined by it, despite his rather extraordinary innovations. For this reason, he was able to develop his views and practices in a basically Anglican way. Yet since the Methodist societies were never given official status within the Anglican Church, they developed independently under Wesley, rather than being officially recognized as an evangelical Anglican order. Of course, this led to Methodism's separation from the Church of England after Wesleys' death, leaving Methodists as ecclesiological orphans. Some have said Methodism has ever since been "a movement in search of a church." John Wesley himself appears to have hoped, at least early on, for some kind of official Methodist recognition within the Church of England. If that had happened, the history of Methodism - and probably of Anglicanism - would have been much different.

Many of the distinctive features of Wesley's concept of the church trace largely to the peculiar position of Methodism within Anglicanism. If Methodism had arisen within the Roman Catholic Church, it might have become a recognized order. However if Methodism had been born two centuries earlier within Reformation Protestantism, it would likely have been forced to become a separate believers' church, much like the Mennonites.

It will always be argued (from both sides) that Wesley's institutional-charismatic synthesis is fundamentally inconsistent and impossible. I argue rather that it is part of the larger Wesleyan synthesis. I believe Wesley's fundamental perspective is essentially sound and insightful when viewed biblically, historically, and sociologically, and thus it is very relevant today.

Wesley's genius was in balancing the charismatic and institutional dimensions of the church, yet keeping the charismatic primary. The Wesleyan synthesis does not flee from history into pure existentialism or pragmatism. It keeps the present creatively tied to the past. Methodism sought to be neither above history nor shackled by tradition. This was the basis for Wesley's seeing Methodism as ecclesiola in ecclesia - charismatic community (not entirely unstructured) within the institutional church (not entirely lacking grace).

\section{Present and Future Salvation}

Finally, the Wesleyan synthesis balances present and future salvation. No one would accuse Wesley of underemphasizing eternal blessedness with God. In fact, Wesley's understanding of the kingdom of God may at times appear too otherworldly 
and too static to be fully biblical. But Wesley's emphasis on sanctification centered in the present reality of the life of God in the human soul. It was a progressive, dynamic concept. Wesley reasoned that if holiness could come at death, God's Spirit could just as surely enable us to live holy lives now.

Wesley stressed "all inward and outward holiness" on biblical grounds. He kept Christian experience from retreating into a private inner world divorced from the problems and sufferings of daily life. Holiness involved making a present stand for the justice and righteousness of the kingdom of God, and especially bringing the gospel to the poor. Wesley often summarized this with the phrase, "justice, mercy, and truth."

In his theology and in his life and practice, Wesley combined the emphases of eschatological hope and final judgment, present and future salvation, and the evangelistic and prophetic dimensions of the gospel. Because salvation is for eternity, Wesley was an evangelist who preached "the wrath to come." Because salvation is for the present, Wesley reached the poor and worked for social reform. This too is evidence of the Wesleyan synthesis. And it helps set the task set before the church today.

This is the Wesleyan Synthesis. John Wesley was a "both/and" leader who creatively joined together these five sets of concerns that are often viewed as being in tension: 1) divine sovereignty and human freedom, 2) doctrine and experience, 3) experience and structure, 4) charismatic and institutional perspectives, and 5) present and future salvation.

\section{WESLEYAN QUADRILATERAL REVISITED: The Wisdom of God in Creation}

The comprehensiveness of Wesley's theology has often been affirmed through describing a "Wesleyan Quadrilateral" consisting of Scripture, reason, tradition, and experience. The quadrilateral has become a popular way of describing Wesley's theology or his theological method.

The Wesleyan Quadrilateral has been much used, abused, and criticized. Although it is useful, it is also inadequate. Its major flaw is that it fails to appreciate Wesley's appeal to the created order, his emphasis on "the wisdom of God in creation." 22

22 There is a large literature on the Wesleyan Quadrilateral. For an overview see Howard A. Snyder, Yes in Christ: Wesleyan Reflections on Gospel, Mission, and Culture, Tyndale Studies in Wesleyan History and Theology, Vol. 2 (Toronto: Clements Academic, 2011), 41-90; Donald A. D. Thorsen, The Wesleyan Quadrilateral: Scripture, Tradition, Reason and Experience as a Model of Evangelical Theology (Grand Rapids: Zondervan, 1990); Ted A. Campbell et al., Wesley and the Quadrilateral: Renewing the 
A fully Wesleyan theology therefore requires transcending the Wesleyan Quadrilateral of Scripture, reason, tradition, and experience as sources of authority in theology.

The Quadrilateral does preserve key insights. It reminds us that Wesley was heir not only to the Protestant Reformation but also to Anglicanism, which sought to preserve the best of Roman Catholicism. Partly for this reason, Wesley generally refused rigid either/or categories.

The Reformation watchword of Sola scriptura is right in affirming Scripture as the essential, authoritative revealed basis of salvation. But of course in practice we do more than read Scripture in our search for truth. We read it through our rational, experiential, and cultural lenses. We are in fact shaped by tradition and experience, and we use reason to sort out truth and mediate competing claims.

Wesley, however, made use of another key source - the created order. He spoke of "the wisdom of God in creation." Thus we really find in Wesley something more like a pentalateral, not a quadrilateral. That is, not only Scripture, reason, tradition, and experience, but also creation. We discern truth primarily through Scripture by the Spirit, but we are assisted by these other good gifts of God: Reason, the created order, experience, and tradition. ${ }^{23}$

Wesley was explicit about the key role of the created universe. He wrote in his sermon, "God's Approbation of His Works," "How small a part of this great work of God [in creation are we] able to understand! But it is our duty to contemplate what he has wrought, and to understand as much of it as we are able." 24 For Wesley, such "contemplation" is a theological, not just a devotional, exercise.

Wesley's reliance on the created order as a source of insight and authority runs through all his thought. A particularly pointed statement comes early in his Compendium of Natural Philosophy, Being a Survey of the Wisdom of God in the Creation:

In short, the world around us is the mighty volume wherein God hath declared himself... Life subsisting in millions of different forms, shows the vast diffusion of this animating power, and death the infinite disproportion between him and every living thing. Even the actions of animals are an eloquent and a pathetic

Conversation (Abingdon, 1997); Randy L. Maddox and Jason E. Vickers, eds., The Cambridge Companion to John Wesley (New York: Cambridge University Press, 2010), 111, 312, 315.

${ }^{23}$ It will not do to "fix" the quadrilateral by subsuming creation under one of the other elements, as some have suggested-reason or experience, for instance. While creation may in some sense be implicit in all four elements, it must be made explicit in order to avoid misunderstanding Wesley's theology, his theological methodology, and his spirituality.

24 Wesley, Sermon 56, “God's Approbation of His Works," 2. 
language. Those that want the help of man have a thousand engaging ways, ... Thus it is, that every part of nature directs us to nature's God. ${ }^{25}$

Wesley explains in his Preface to A Compendium of Natural Philosophy, "I wished to see this short, full, plain account of the visible creation, directed to its right end; not barely to entertain an idle barren curiosity, but to display the invisible things of God; his power, wisdom and goodness." Wesley hoped this work, "in great measure, translated from the Latin work of John Francis Buddæus," might "be the means, on the one hand, of humbling the pride of man, by showing that he is surrounded on every side with things which he can no more account for than for immensity or eternity; and it may serve on the other to display the amazing power, wisdom, and goodness of the great Creator; to warm our hearts, and to fill our mouths with wonder, love, and praise!"26

Wesley's primary point here is that the created order reveals God's wisdom, glory, and beauty, leading us to praise him and live responsibly before him in the world. ${ }^{27}$ But this implies, as well, revelation - creation is the God-given "book of nature." It is in the light of this book of nature that we interpret the Scriptures, and vice versa.

Wesley was part of a long Christian tradition that saw God revealing himself in two great books: the Holy Bible and the Book of Nature. Both came from the hand of God as complementary dimensions of his revelation. Therefore we should pay attention to and learn both from Scripture and from the created order. Both are in fact essential to our understanding of God's purposes for us and for the world. Wesley emphasized that it is the Christian's duty to study and properly interpret both the Bible and the Book of Nature. ${ }^{28}$ Unfortunately, this Wesleyan emphasis on the Book of Nature was largely lost in later Wesleyan theology. If we would be Wesleyan - and more importantly, if we would be biblical Christians and disciples - we need to recover this important Wesleyan and historic Christian accent.

One key way to do this is to recognize that the so-called Wesleyan Quadrilateral is incomplete without it. A more truly Wesleyan Quadrilateral, if we wish to use such a

25 John Wesley, A Compendium of Natural Philosophy, Being a Survey of the Wisdom of God in the Creation, "A New Edition," ed. Robert Mudie, 3 vols. (London, UK: Thomas Tegg and Son, 1836), 2:370f.

26 Wesley, Compendium, 1:iii-vi.

27 Barry Bryant notes the "pronounced aesthetic theme" in Wesley's doctrine of creation. See Barry Bryant, "John Wesley on the Origins of Evil," Wesleyan Theological Journal 30:1 (Spring 1995), 133, and the discussion in Jerry L. Walls, "As the Waters Cover the Sea': John Wesley on the Problem of Evil," Faith and Philosophy 13:4 (Oct. 1996), 537.

${ }^{28}$ For essential background on the Book of Nature and its interpretation, see Peter Harrison, The Bible, Protestantism, and the Rise of Natural Science (Cambridge: Cambridge University Press, 1998, 2001), especially 44-48, 62-63, 195-97, and 263-64. 
geometric image, would be as follows: the four corners would be Creation, Tradition, Reason, and Experience, with the Bible in the center.

If we discern Wesley's theological methodology inductively from his own writings and use of sources, this is what we find, rather than the traditional model. Luís Wesley de Souza has cogently argued this in his essay, "'The Wisdom of God in Creation': Mission and the Wesleyan Pentalateral."29 In this revised model, Creation is added to Scripture, Reason, Tradition, and Experience as a fifth component. ${ }^{30}$

De Souza recognizes the limitations of such quadrilateral/pentalateral language. Although he uses the term "Pentalateral," the model he proposes actually puts Scripture at the center with reason, creation, experience, and tradition arrayed around it, as I suggested above. ${ }^{31}$ This moves in the direction of a more adequate conception-one that keeps Scripture central, as it was for Wesley, and sees creation, tradition, reason, and experience as key sources that dynamically orbit around this center (to pick up on some helpful insights from Melvin Dieter). ${ }^{32}$

We should note here Wesley's key emphasis on the image of God at this point. The image of God in men and women was part of his understanding of creation. Man and woman are created in the divine image. For Wesley, this is much more than an affirmation about human worth or dignity (as it is often taken today). It has key redemptive implications. Since human beings bear God's image, even though marred by sin, they can be redeemed, healed, restored. Created in the divine image, men and women are "capable of God."33 That is, human beings have an inherent capacity for deep communion and companionship with God if the effects of sin can be overcome. This reality and dynamic is grounded in the biblical doctrine of creation.

29 Luís Wesley de Souza, “'The Wisdom of God in Creation': Mission and the Wesleyan Pentalateral," in Howard A. Snyder, ed., Global Good News: Mission in a New Context (Nashville, Tenn.: Abingdon, 2001), 138-152.

30 See Snyder, Radical Wesley, 83.

31 See De Souza's graphic, p. 143 of Global Good News.

32 See the summary of Dieter's model in Catherine Stonehouse, Joining Children on the Spiritual Journey (Grand Rapids, Mich.: Baker, 1998), 16-20, 215f. Maddox says, "Wesley's so-called 'quadrilateral' of theological authorities could more adequately be described as a unilateral rule of Scripture within a trilateral hermeneutic of reason, tradition, and experience" (Responsible Grace, 46). I would say, rather: A unilateral or central rule of Scripture within a quadrilateral of creation, reason, tradition, and experience.

33 A phrase Wesley used repeatedly, especially in his sermon "The General Deliverance," as did Charles occasionally in his hymns. 
According to Wesley, the whole created order in fact, in a more remote sense, bears God's stamp and image. ${ }^{34}$ This is more particularly true of animate nature, where the wisdom of God was especially displayed. Wesley believed on philosophical and theological grounds that more could be learned about God from the animal creation than from stars and planets. Theologically, we learn more from biology than from astronomy, though Christians should study both. ${ }^{35}$

We can see here that Wesley's worldview is more Hebraic and biblical than Greek or Platonic. Partly for this reason, it is more ecological, "both/and," than is most Reformed theology. In his mature theology especially, Wesley did not make a sharp break between the physical and the spiritual realms. It was no theological embarrassment to him to see the interpenetration of matter and spirit. He emphasized the working of God's Spirit in both, interactively.

Wesley's interest in healing, in electricity, and in so-called paranormal phenomena such as ghosts and unusual dreams should be seen in this context. This integrative view provides, in part, the theological basis for recognizing that salvation has to do not only with human experience but also with the restoration of the whole created order, which is another key Wesley theme.

I do not claim that Wesley fully overcame the spirit/matter dualism of classical Christian theology. He didn't. But he points us in the right direction with his oftrepeated stress on "all inward and outward holiness"; in his key theme of "justice, mercy, and truth"; and in his sensitivity to the created order, concern for physical healing and well-being, and compassion for animals. Even his interest in gardens and gardening shows the comprehensiveness of Wesley's vision.

Wesley points us in the right direction especially in his vision for the restoration of the created order. Wesley called this “The Great Deliverance," based on Romans 8:19-

${ }^{34}$ As Theodore Runyon notes, "The renewal of the creation and the creatures through the renewal in humanity of the image of God is what Wesley identifies as the very heart of Christianity." Theodore Runyon, The New Creation: John Wesley's Theology Today (Nashville, Tenn.: Abingdon, 1998), 8 (emphasis in the original).

35 In the background here in Wesley's thought is the "great chain of being" idea. More fundamentally however his view is based on the biblical account of creation and of the importance of the image of God. See the helpful discussion in J. W. Haas, Jr., "John Wesley's Vision of Science in the Service of Christ," Perspectives on Science and Christian Faith 47 (1995), 234-43. 
22, which speaks of all creation being "delivered" or "set free" from its "bondage to decay." 36

Here Wesley reveals a remarkable ecological sensitivity. Wesley lived before the word ecology became current, but he clearly describes the concept in some of his writing. As Theodore Runyon notes, Wesley's view of the original harmony of the created order (to be restored in the new creation) is essentially "what today would be called ecological balance."37

Some of Wesley's ideas and speculations about the restoration of creation, as for instance in his sermon "The General Deliverance," may today sound quaint, romantic, or unscientific. They should not for that reason be dismissed. We should note the important theological move Wesley is making. He extends salvation to the whole created order, not just human beings, just as the Bible does in Romans 8:19-22 and many other passages.

In his sermon "The General Deliverance," Wesley wrote, "Something better" than their present fallen state "remains after death for these poor creatures." Like us, they "shall one day be delivered from this bondage of corruption, and shall then receive an ample amends for all their present sufferings."

In view then of God's care and ultimate intent for his creation, we ourselves should "imitate him whose mercy is over all his works." We should "soften our hearts towards [animals and other] creatures, knowing that the Lord careth for them" and will redeem them in the New Creation. It should "enlarge our hearts towards those poor creatures," Wesley says, "to reflect that ... not one of them is forgotten in the sight of our Father which is in heaven." 38

Wesley had a deep conviction that in bringing full salvation, God would redeem and restore the whole created order, not just human beings. This is indeed the "universal restoration that God announced long ago through his holy prophets" (Acts 3:21), as Peter proclaimed in his post-Pentecost sermon recorded in Acts 3.

Wesley believed this because the healing of all creation is the larger truth he found in the Bible. It is a biblical theme which Wesleyan theology has largely ignored,

${ }^{36}$ See Sermon 60, "The General Deliverance." Based on the KJV of Acts 3:21, Wesley envisioned, hoped for, and spoke of "the restitution [i.e., restoration] of all things." See for example Sermon 4, "Scriptural Christianity," 3; Sermon 39, "Catholic Spirit," I.3.

${ }^{37}$ Runyon, New Creation, 10 (emphasis in the original).

${ }^{38}$ Wesley, Sermon 60, "The General Deliverance," III.9, 10. 
but which is especially important in our day. It is a truth that needs emphasis by the Church of Jesus Christ throughout the world-not as a separate theme, but as an integral part of the whole gospel.

\section{CONCLUSION: RELEVANCE TODAY}

This article has provided an overview of Wesley as theologian. We have looked at Wesley's theology in two ways: First, reviewing what I call the Wesleyan Synthesis, and second, reconsidering the Wesleyan Quadrilateral in view of Wesley's strong interest in and theological use of the created order, or the Book of Nature.

From this analysis I would now draw three general conclusions. First, Wesley's theology was broader and more profound than has often been realized. Due to his particular gifts, his location in history, his commitment to Scripture, and his openness to the work of the Holy Spirit, Wesley developed an approach to theology which is highly relevant today, globally. Wesley's theology was based in an uncompromising adherence to biblical revelation and authority. To be Wesleyan and genuinely Christian requires maintaining the Wesleyan commitment to Scripture and to Jesus Christ-the Written Word and the Living Word, properly interpreted.

Second, Wesley's theology can help us develop a biblical understanding of culture and culture change. Due to the depth of his theology, his openness to "the wisdom of God in creation," including human nature, science, and human culture, Wesley's theology is an open door to further explore the nature of culture and the processes of social change.

Wesleyan and biblical Christians can develop a deepened, more timely view of culture today, following the directions in which Wesley incipiently pointed. This of course means moving well beyond Wesley-in culture as in science-due to continuing new discoveries and due to the fact that the church today is global, embedded in many different cultures. From our varying cultures, and drawing on the riches of each culture, we can develop a theology of church, culture, and mission that has deep relevance and profound commitment to Jesus Christ and the biblical gospel of the kingdom. This includes the great need for Christians to understand the deep ecology of the created order, of human culture, and of biblical theology itself.

Third, Wesley's theology is thus an open invitation to continue to develop a theology of church, mission, and culture that is profoundly biblical and sharply relevant to the present age. We can affirm with Wesley and the Great Tradition of Christian truth 
that God has revealed himself through two great books - the Holy Bible and the Book of Nature. Both testify in their own ways to Jesus Christ, the one who is "before all things" and in whom "all things hold together" (Col 1:17). "All things came into being through him, and without him not one thing came into being. What has come into being in him was life, and the life was the light of all people" (John 1:3-4).

This then is an invitation to a broadened application for John Wesley's theology as one key voice among many. Wesley's contribution is an orienting voice, a voice that points us in the right direction. Nowhere is this more true than in Wesley's conception of God and the whole Scripture: The full scope of salvation, and the wisdom of God in creation.

This certainly does not mean abandoning Wesley's call to holiness! Rather it means a new emphasis upon devout, holy living for each one of us, and as the character of Christian community and Christian scholarship. Wesley repeatedly points us back to the priority of "all inward and outward holiness." Most essentially, this means loving God with all our heart, soul, mind, and strength, and our neighbors throughout the world as ourselves - as well as our shared earthly home, the good creation around us. So today we are called to live the gospel; to faithfully be the body of Christ in the world.

\section{REFERENCE}

Bryant, Barry. "John Wesley on the Origins of Evil," Wesleyan Theological Journal Vol.30, No.1 (Spring 1995): 111-133. https://wtsociety.com/files/wts_journal/1995-wtj-30-1.pdf.

Campbell, Ted A. et al., Wesley and the Quadrilateral: Renewing the Conversation. Abingdon, 1997.

Cell, George Croft. personal letter quoted in E. D. Soper, "Grace in Methodist Tradition," in W. T. Whitley, ed., The Doctrine of Grace. New York: Macmillan, 1932.

de Souza, Luís Wesley. “The Wisdom of God in Creation': Mission and the Wesleyan Pentalateral," in Howard A. Snyder, ed., Global Good News: Mission in a New Context Nashville, Tenn.: Abingdon, 2001.

Dorner, Isaac. History of Protestant Theology, trans. George Robson and Sophia Tucker Edinburgh: T. and T. Clark, 1871.

Harrison, Peter. The Bible, Protestantism, and the Rise of Natural Science. Cambridge: Cambridge University Press, 1998, 2001.

Haas, Jr., J.W. “John Wesley's Vision of Science in the Service of Christ," Perspectives on Science and Christian Faith Vol.47 (1995), 234-243. 
Lovelace, Richard F. Dynamics of Spiritual Life: An Evangelical Theology of Renewal. Downers Grove, III: InterVarsity Press, 1979.

Maddox, Randy L. “John Wesley's Precedent for Theological Engagement with the Natural Sciences," Wesleyan Theological Journal Vol.44, No.1 (2009): 23-54. https://wtsociety.com/files/wts_journal/2009-wtj-44-1.pdf.

Maddox, Randy L. and Jason E. Vickers, eds., The Cambridge Companion to John Wesley. New York: Cambridge University Press, 2010.

Oden, Thomas. Intensive Group Experience, The New Pietism. Philadelphia: Westminster, 1972.

Olson, Roger. Arminian Theology: Myths and Realities. Downers Grove: InterVarsity, 2006.

Runyon, Theodore. The New Creation: John Wesley's Theology Today. Nashville, Tenn.: Abingdon, 1998.

Snyder, Howard A. Signs of the Spirit: How God Reshapes the Church (Grand Rapids: Zondervan, 1989.

Snyder, Howard A. The Problem of Wineskins. Downers Grove. Ill.: InterVarsity, 1975.

Snyder, Howard A. The Radical Wesley: The Patterns and Practices of a Movement Maker. Franklin, Tenn.: Seedbed Publishing, 2014.

Snyder, Howard A. Yes in Christ: Wesleyan Reflections on Gospel, Mission, and Culture, Tyndale Studies in Wesleyan History and Theology, Vol.2 Toronto: Clements Academic, 2011.

Stonehouse, Catherine. Joining Children on the Spiritual Journey. Grand Rapids, Michigan: Baker, 1998.

Telford, John. The Life of John Wesley (New York: Phillips and Hunt, 1886), 147; Sydney G. Dimond, The Psychology of the Methodist Revival. Oxford: Oxford University Press, 1926

Thorsen, Donald A. D. The Wesleyan Quadrilateral: Scripture, Tradition, Reason and Experience as a Model of Evangelical Theology. Grand Rapids, Michigan: Zondervan, 1990.

Walls, Jerry L. "As the Waters Cover the Sea: John Wesley on the Problem of Evil." Faith and Philosophy: Journal of the Society of Christian Philosophers Vol.13, Iss.4 (1996): 534-562. https://doi.org/10.5840/faithphil199613446.

Wesley, John. A Compendium of Natural Philosophy, Being a Survey of the Wisdom of God in the Creation, "A New Edition," ed. Robert Mudie, 3 vols. London, UK: Thomas Tegg and Son, 1836.

Wesley, John; Albert C Outler; Frank Baker; Richard P Heitzenrater; Randy L Maddox. “Wesley's Journal." in The Works of John Wesley. Bicentennial Ed., Nashville: Abingdon Press, 1984, 22:55. August 27, 1768. All references to Wesley's Works are from this multivolume edition unless otherwise noted.

Williams, Colin. John Wesley's Theology Today. Nashville: Abingdon Press, 1960. 